\title{
Surgical Laparotomy for Repeated Delayed Arterial Hemorrhage after Pancreaticoduodenectomy
}

\author{
Kenji Mimatsu ${ }^{a}$ Nobutada Fukino $^{a}$ Hisao Kano $^{b}$ Atsushi Kawasakic \\ Takatsugu Oidad \\ aDepartment of Surgery, Japan Community Healthcare Organization, Yokohama Chuo \\ Hospital, Yokohama, Japan; bepartment of Gastroenterological Surgery, Nihon University \\ School of Medicine, Tokyo, Japan; 'Department of Surgery, Tokyo Hernia Center, \\ Tokyo, Japan; ${ }^{d}$ Department of Surgery, Kiba Hospital, Tokyo, Japan
}

\section{Keywords}

Laparotomy · Delayed arterial hemorrhage · Pancreaticoduodenectomy

\begin{abstract}
Postpancreatectomy hemorrhage is one of the major life-threatening complications of pancreatic surgery. Radiological intervention is used as a first-line approach for the initial treatment of late arterial hemorrhage. However, rehemorrhage has a high risk for mortality, and it is undecided which urgent intervention provides optimal management for rehemorrhage. We experienced a successful surgical laparotomy for the repeated delayed arterial hemorrhage caused by a pancreaticoduodenectomy (PD) for chronic pancreatitis. A 57-year-old man had undergone PD with pancreaticogastrostomy for tumor-forming pancreatitis with possible pancreatic cancer. A delayed massive hemorrhage from the drain developed 11 days after surgery. Although angiography was done, the bleeding site was not clearly detected. Therefore, urgent surgical laparotomy was performed. Arterial bleeding was detected from the stump of the gastroduodenal artery. Surgical ligation, using the suture technique, was performed for
\end{abstract}




\section{Case Reports in Gastroenterology}

Case Rep Gastroenterol 2019;13:50-57

DOI: 10.1159/000496918

(c) 2019 The Author(s). Published by S. Karger AG, Base www.karger.com/crg

Mimatsu et al.: Surgical Laparotomy for Repeated Delayed Arterial Hemorrhage after Pancreaticoduodenectomy

hemostasis, and a closed drain was placed in the area due to drainage of pancreatic juice and an abscess. However, rehemorrhage from the drain developed 7 days after the initial hemorrhage. Relaparotomy was performed immediately. The surgical ligation and compression hemostasis with absorbable hemostatic cotton was done. After relaparotomy for rehemorrhage, there was no hemorrhage or fatal hepatic failure. He left our hospital 64 days after initial surgery. Surgical laparotomy is one of the feasible procedures for hemostasis of a massive arterial hemorrhage. Proper blood vessel ligation is necessary for reliable hemostasis and proper drainage of pancreatic juice and abscesses to prevent hemorrhage. (c) 2019 The Author(s)

Published by S. Karger AG, Basel

\section{Introduction}

Postpancreatectomy hemorrhage (PPH) is uncommon but still one of the major lifethreatening complications. The incidence of PPH is relatively low at 6-7.2\%, but it nevertheless has a high mortality rate of 14.1-20\% [1, 2]. According to the International Study Group of Pancreatic Surgery (ISGSP), PPH is classified into early PPH, occurring in the first $24 \mathrm{~h}$ postoperatively, and late PPH, occurring $24 \mathrm{~h}$ after operation [3]. Because of the different pathogeneses between early and late PPH, the treatment is different. Early PPH is mainly due to the nonsecured ligation of vessels, such as the suture line of the anastomosis or areas of resection, whereas late PPH mainly originates from the erosion or pseudoaneurysm of major arteries, which is often related to pancreatic fistulas and intra-abdominal abscesses [4]. Thus, early $\mathrm{PPH}$ often requires urgent reoperation for hemostatic management. However, late PPH is treated with radiological intervention and endoscopy as a first-line approach. However, management of rehemorrhage after the initial treatment for late PPH is controversial. It is difficult to control rehemorrhage, and there is no satisfying treatment for massive rehemorrhage with a severe pancreatic fistula and/or intra-abdominal abscess.

We report a rare case of successful relaparotomy for a massive arterial rehemorrhage from the stump of the gastroduodenal artery, and we review cases of rehemorrhage after hemostasis by the initial treatment for late intra-abdominal hemorrhage after pancreaticoduodenectomy (PD).

\section{Case Presentation}

A 57-year-old man underwent subtotal stomach-preserving PD with pancreaticogastrostomy for tumor-forming pancreatitis with possible pancreatic cancer. Surgical findings revealed adhesions around the pancreas head that were attributable to chronic pancreatitis. The patient developed a pancreatic fistula due to leakage at the pancreaticogastric anastomosis. On the 10th postoperative day, a bloody secretion was discharged through the abdominal drain tube. He was hemodynamically stable, but the decrease in hemoglobin required a blood transfusion with 4 units of packed red cells. Computed tomography indicated the presence of fluid collection, containing small gas bubbles anterior to the portal vein and hepatic artery in the abdominal space (Fig. 1). The next day (postoperative day 11), following reappearance of bleeding from the abdominal drainage and a sudden drop in pressure, an angiography was 


\section{Case Reports in Gastroenterology}

Case Rep Gastroenterol 2019;13:50-57

DOI: 10.1159/000496918

(c) 2019 The Author(s). Published by S. Karger AG, Basel www.karger.com/crg

Mimatsu et al.: Surgical Laparotomy for Repeated Delayed Arterial Hemorrhage after Pancreaticoduodenectomy

done immediately. Although angiography showed a suspected pseudoaneurysm originating from the common hepatic artery, the origin of bleeding could not be clearly identified (Fig. 2). Because the bleeding point was not clearly identified, the decision was made to proceed with an urgent explorative laparotomy. A large hematoma was found in the upper abdominal space close to the pancreaticogastric anastomosis. The source of bleeding was detected from the stump of the gastroduodenal artery (Fig. 3). The bleeding point was sewn with a nonabsorbable suture, and the area was drained with a large bore soft drain. Operative time was 174 min, and blood loss was 1,680 mL. Transfusion was required, and 4 units of packed red blood cells and 3 units of fresh frozen plasma were given during surgery. However, rehemorrhage from the abdominal drain developed on the 7th day after relaparotomy. We selected a relaparotomy for ligation of the bleeding point, because it was considered highly possible that hemostasis using transarterial embolization (TAE) was difficult due to potential rehemorrhage from the site of the initial hemorrhage. Thus, we performed an urgent relaparotomy and controlled the rehemorrhage by sewing the bleeding point with a nonabsorbable suture and compressing the area with absorbable hemostatic cotton. Operative time was $160 \mathrm{~min}$, and blood loss was 2,790 mL. A blood transfusion with 4 units of packed red cells and 3 units of packed fresh frozen plasma were required during surgery. After relaparotomy, there was no further hemorrhage. Fortunately, he did not have a coagulation disorder or fatal hepatic failure and was discharged from our hospital 64 days after initial surgery.

\section{Discussion}

This patient's course provided two important clinical suggestions. Surgical laparotomy is one of the feasible procedures for massive delayed arterial PPH in cases where the bleeding point cannot be clearly identified. Proper blood vessel ligation is necessary for reliable hemostasis and proper drainage of pancreatic juice and abscesses to prevent delayed arterial PPH.

Surgical laparotomy is one of the feasible procedures for hemostasis of a massive delayed arterial hemorrhage in cases where the bleeding point cannot be clearly identified and after failed TAE. Recently, radiological interventions, such as TAE or covered intraluminal stenting, have become the standard first-line procedures for management of PPH instead of surgical intervention [5]. However, the prognosis of late PPH remains poor, despite advances such as radiological diagnosis or the technology of angiography [6]. Wellner et al. [1] showed that the success rate of radiological intervention was $50 \%$, and in the remaining $50 \%$, there was no target because of intermittent bleeding cessation or hemostasis being technically not feasible. There is a meta-analysis that evaluated delayed hemorrhage after PD, which found no difference between angiography and operative interventions [7]. Therefore, it is difficult to determine whether radiological interventions or surgical interventions provide optimal management of late arterial PPH. Surgical laparotomy is still irreplaceable and is considered to be the only option for rapidly deteriorating patients with unstable hemodynamics where hemostasis by TAE was not technically feasible or after failed TAE.

Proper blood vessel ligation is necessary for reliable hemostasis and proper drainage of pancreatic juice and abscesses to prevent arterial hemorrhage. Late arterial PPH was a secondary complication caused by a pancreatic fistula and intra-abdominal abscess. Intra-abdominal hemorrhage after PD is closely associated with pancreatic fistula, and the incidence 


\section{Case Reports in Gastroenterology}

Case Rep Gastroenterol 2019;13:50-57

DOI: 10.1159/000496918

(c) 2019 The Author(s). Published by S. Karger AG, Base www.karger.com/crg

Mimatsu et al.: Surgical Laparotomy for Repeated Delayed Arterial Hemorrhage after Pancreaticoduodenectomy

is $44.4-100 \%$ [4, 6, 8-17] (Table 1). Rehemorrhage is especially closely associated with a severe pancreatic fistula and intra-abdominal abscess [6]. Damage control procedures, including bleeding control, abscess drainage, pancreatic duct fistulation, and completion pancreatectomy, are the cornerstone treatments for repeated PPH. Surgical laparotomy is necessary for optimal hemostasis of a massive arterial hemorrhage and proper drainage of pancreatic leakage and an intra-abdominal abscess. In the present case, hemostatic treatment using the sewing technique and abscess drainage was performed for the initial hemorrhage; however, rebleeding developed 7 days after surgical laparotomy. Hemostasis using the ligation technique for an arterial hemorrhage is often difficult for vascular fragility due to inflammation influenced by pancreatic fistula and infection. Thus, the bleeding point was sewn with a nonabsorbable suture and compressed with an absorbable hemostatic cotton to control arterial rehemorrhage.

Late hemorrhage after PD is a rare but life-threatening complication with reported morbidity $4.3 \%$ and in-hospital mortality $24.4 \%$ [4, 6, 8-17] (Table 1). In recent years, late arterial hemorrhage has often been treated with radiological intervention as a first-line approach. However, the incidence of rehemorrhage after successful hemostasis is $13.8 \%[4,6,8-17]$ (Table 1). If the hemostatic treatment of rehemorrhage fails, the mortality rate after second treatment is as high as 70\% [6]. It is difficult to control rehemorrhage, especially in patients whose rehemorrhage comes with a severe pancreatic fistula and an intra-abdominal abscess. There is no satisfying treatment for a severe arterial rehemorrhage. Once the bleeding is controlled, vigorous treatment of the pancreatic fistula and abscess is the most effective management to prevent rehemorrhage [6]. Moreover, various surgeons have developed different surgical techniques in an attempt to prevent arterial hemorrhage due to pseudoaneurysm formation. Lee et al. [15] reported that the gastroduodenal artery stump should leave behind a long segment with a Hemolok ${ }^{\circledR}$ clip to minimize the initial gastroduodenal artery injury. We previously reported that protecting the major vessels and pancreaticogastrostomy with the falciform ligament and greater omentum prevented a pancreatic fistula in the soft pancreatic texture after PD [18]. The goal is to prevent an arterial hemorrhage if pancreatic leakage develops after PD. It is most important in delayed arterial PPH to prevent a pancreatic fistula and intra-abdominal abscess.

In conclusion, this case highlights two important issues. It is better to perform emergency laparotomy when the source of the bleeding is unclear and the hemodynamics are unstable based on interventional radiology. Relaparotomy is one of the selective treatments for rehemorrhage after successful hemostasis of delayed arterial PPH.

\section{Statement of Ethics}

Written informed consent was obtained from the patient for publication of this case report and any accompanying images.

\section{Disclosure Statement}

The authors declare that there is no conflict of interest related to this case report. 


\section{Case Reports in Gastroenterology}

Case Rep Gastroenterol 2019;13:50-57

(C) 2019 The Author(s). Published by S. Karger AG, Base www.karger.com/crg

Mimatsu et al.: Surgical Laparotomy for Repeated Delayed Arterial Hemorrhage after Pancreaticoduodenectomy

\section{References}

1 Wellner UF, Kulemann B, Lapshyn H, Hoeppner J, Sick O, Makowiec F, et al. Postpancreatectomy hemorrhage-incidence, treatment, and risk factors in over 1,000 pancreatic resections. J Gastrointest Surg. 2014 Mar;18(3):464-75.

2 Asari S, Matsumoto I, Toyama H, Yamaguchi M, Okada T, Shinzeki M, et al. Recommendation of treatment strategy for postpancreatectomy hemorrhage: lessons from a single-center experience in 35 patients. Pancreatology. 2016 May-Jun;16(3):454-63.

3 Wente MN, Veit JA, Bassi C, Dervenis C, Fingerhut A, Gouma DJ, et al. Postpancreatectomy hemorrhage (PPH): an International Study Group of Pancreatic Surgery (ISGPS) definition. Surgery. 2007 Jul;142(1):205.

4 Tien YW, Lee PH, Yang CY, Ho MC, Chiu YF. Risk factors of massive bleeding related to pancreatic leak after pancreaticoduodenectomy. J Am Coll Surg. 2005 Oct;201(4):554-9.

5 Wolk S, Grützmann R, Rahbari NN, Hoffmann RT, Plodeck V, Weitz J, et al. Management of clinically relevant postpancreatectomy hemorrhage (PPH) over two decades - A comparative study of 1450 consecutive patients undergoing pancreatic resection. Pancreatology. 2017 Nov - Dec;17(6):943-50.

6 Feng J, Chen YL, Dong JH, Chen MY, Cai SW, Huang ZQ. Post-pancreaticoduodenectomy hemorrhage: risk factors, managements and outcomes. Hepatobiliary Pancreat Dis Int. 2014 0ct;13(5):513-22.

$7 \quad$ Limongelli P, Khorsandi SE, Pai M, Jackson JE, Tait P, Tierris J, et al. Management of delayed postoperative hemorrhage after pancreaticoduodenectomy: a meta-analysis. Arch Surg. 2008 0ct;143(10):1001-7.

8 Sato N, Yamaguchi K, Shimizu S, Morisaki T, Yokohata K, Chijiiwa K, et al. Coil embolization of bleeding visceral pseudoaneurysms following pancreatectomy: the importance of early angiography. Arch Surg. 1998 Oct;133(10):1099-102.

9 Rumstadt B, Schwab M, Korth P, Samman M, Trede M. Hemorrhage after pancreatoduodenectomy. Ann Surg. 1998 Feb;227(2):236-41.

10 Yoon YS, Kim SW, Her KH, Park YC, Ahn YJ, Jang JY, et al. Management of postoperative hemorrhage after pancreatoduodenectomy. Hepatogastroenterology. 2003 Nov-Dec;50(54):2208-12.

11 Santoro R, Carlini M, Carboni F, Nicolas C, Santoro E. Delayed massive arterial hemorrhage after pancreaticoduodenectomy for cancer. Management of a life-threatening complication. Hepatogastroenterology. 2003 Nov-Dec;50(54):2199-204.

12 Choi SH, Moon HJ, Heo JS, Joh JW, Kim YI. Delayed hemorrhage after pancreaticoduodenectomy. J Am Coll Surg. 2004 Aug;199(2):186-91.

13 Fujii Y, Shimada H, Endo I, Yoshida K, Matsuo K, Takeda K, et al. Management of massive arterial hemorrhage after pancreatobiliary surgery: does embolotherapy contribute to successful outcome? J Gastrointest Surg. 2007 Apr;11(4):432-8.

14 Beyer L, Bonmardion R, Marciano S, Hartung 0, Ramis O, Chabert L, et al. Results of non-operative therapy for delayed hemorrhage after pancreaticoduodenectomy. J Gastrointest Surg. 2009 May;13(5):922-8.

15 Lee HG, Heo JS, Choi SH, Choi DW. Management of bleeding from pseudoaneurysms following pancreaticoduodenectomy. World J Gastroenterol. 2010 Mar;16(10):1239-44.

16 Jilesen AP, Tol JA, Busch OR, van Delden OM, van Gulik TM, Nieveen van Dijkum EJ, et al. Emergency management in patients with late hemorrhage after pancreatoduodenectomy for a periampullary tumor. World J Surg. 2014 Sep;38(9):2438-47.

17 Huo Y, Chi J, Zhang J, Liu W, Liu D, Li J, et al. Endovascular intervention for delayed postpancreaticoduodenectomy hemorrhage: clinical features and outcomes of transcatheter arterial embolization and covered stent placement. Int J Clin Exp Med. 2015 May;8(5):7457-66.

18 Mimatsu K, Oida T, Kano H, Kawasaki A, Fukino N, Kida K, et al. Protection of major vessels and pancreaticogastrostomy using the falciform ligament and greater omentum for preventing pancreatic fistula in soft pancreatic texture after pancreaticoduodenectomy. Hepatogastroenterology. 2011 Sep-Oct;58(110111):1782-6. 


\section{Case Reports in Gastroenterology}

Case Rep Gastroenterol 2019;13:50-57

(C) 2019 The Author(s). Published by S. Karger AG, Basel www.karger.com/crg

Mimatsu et al.: Surgical Laparotomy for Repeated Delayed Arterial Hemorrhage after Pancreaticoduodenectomy
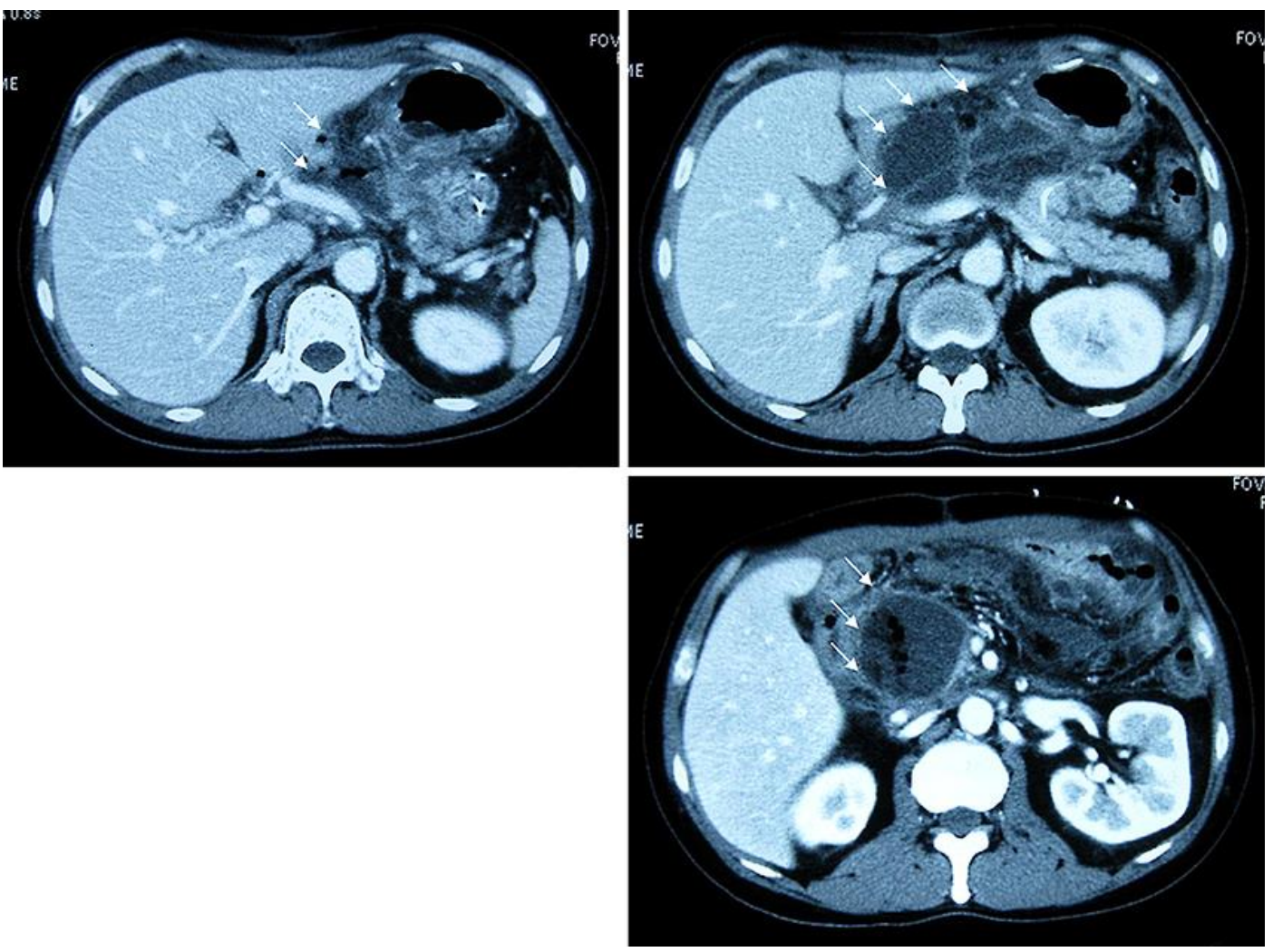

Fig. 1. Computed tomography on the 10th day after PD showed fluid collection (white arrows) causing pancreatic leakage anterior to the major vessels in the abdominal space. 


\section{Case Reports in Gastroenterology}

\begin{tabular}{l|l} 
Case Rep Gastroenterol 2019;13:50-57 \\
\hline DOI: 10.1159/000496918 & $\begin{array}{l}\text { @ 2019 The Author(s). Published by S. Karger AG, Basel } \\
\text { www.karger.com/crg }\end{array}$ \\
\hline
\end{tabular}

Mimatsu et al.: Surgical Laparotomy for Repeated Delayed Arterial Hemorrhage after Pancreaticoduodenectomy

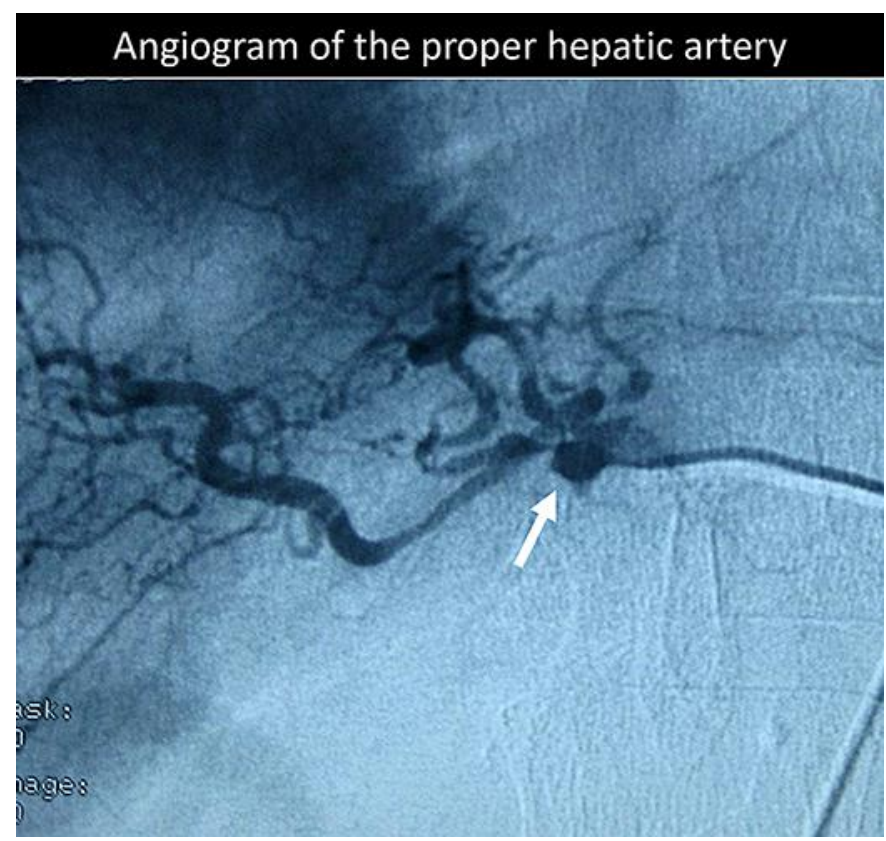

Fig. 2. Angiogram on the 11th day after PD showed a suspected pseudoaneurysm (white arrow) originating from the common hepatic artery. But the bleeding point could not be clearly identified.

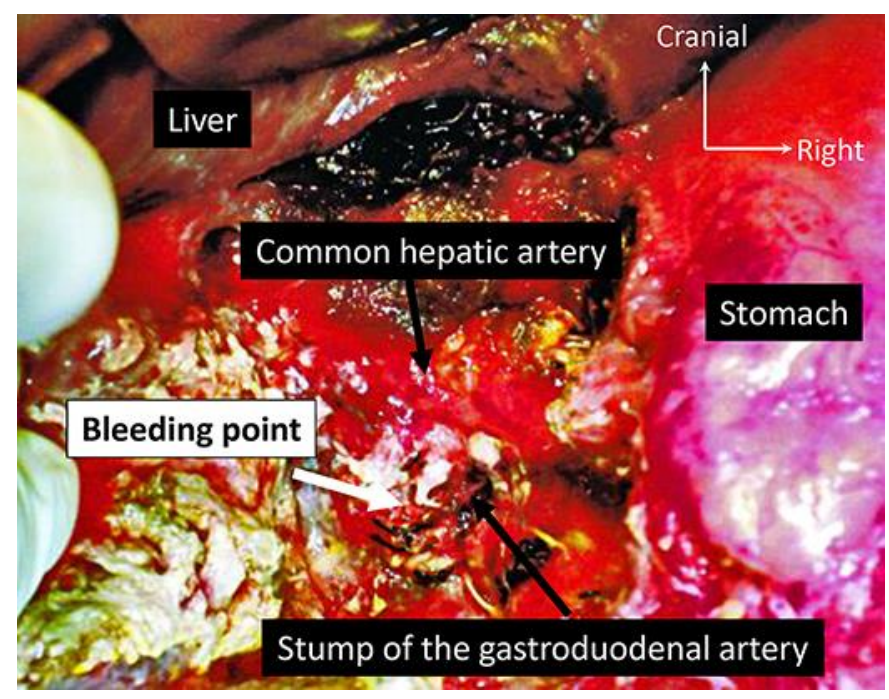

Fig. 3. Operative findings showed the site of bleeding from the common hepatic artery (white arrow). Surgical intervention to treat the bleeding point was performed with the suture technique. 


\section{Case Reports in Gastroenterology}

\begin{tabular}{l|l}
\hline Case Rep Gastroenterol 2019;13:50-57 \\
\hline DOI: 10.1159/000496918 & $\begin{array}{l}\text { @ } 2019 \text { The Author(s). Published by S. Karger AG, Basel } \\
\text { www.karger.com/crg }\end{array}$ \\
\hline
\end{tabular}

Mimatsu et al.: Surgical Laparotomy for Repeated Delayed Arterial Hemorrhage after Pancreaticoduodenectomy

Table 1. Previous reports of late arterial hemorrhage after PD

\begin{tabular}{|c|c|c|c|c|c|c|c|c|c|}
\hline No. & First author [Ref.] & $\begin{array}{l}\text { Year of } \\
\text { publica- } \\
\text { tion }\end{array}$ & Patients & Hemorrhage & $\begin{array}{l}\text { Hemorrhage com- } \\
\text { plicated } \\
\text { with pancreatic fis- } \\
\text { tula }\end{array}$ & $\begin{array}{l}\text { Initial treat- } \\
\text { menta interven- } \\
\text { tion/ } \\
\text { laparotomy/ } \\
\text { another }\end{array}$ & $\begin{array}{l}\text { Rehemorrhage } \\
\text { ter initial treat- } \\
\text { ment }\end{array}$ & $\begin{array}{l}\text { f-Second treat- } \\
\text { mentb interven- } \\
\text { tion/ } \\
\text { laparotomy/ } \\
\text { another }\end{array}$ & $\begin{array}{l}\text { In-hospital mor- } \\
\text { tality after hemor- } \\
\text { rhage }\end{array}$ \\
\hline 1 & Sato [8] & 1998 & 81 & $10(12.3 \%)$ & $6(60 \%)$ & $8 / 1 / 1$ & $1(10 \%)$ & $0 / 1 / 0$ & $4(40 \%)$ \\
\hline 2 & Rumstadt [9] & 1998 & 559 & $20(3.6 \%)$ & $11(55 \%)$ & $0 / 20 / 0$ & $3(15 \%)$ & $3 / 0 / 0$ & $5(25 \%)$ \\
\hline 3 & Yoon [10] & 2003 & 456 & $16(3.5 \%)$ & $10(62.5 \%)$ & $8 / 5 / 4$ & $1(6.3 \%)$ & $0 / 1 / 0$ & $4(25 \%)$ \\
\hline 4 & Santoro [11] & 2003 & 84 & $2(2.4 \%)$ & $2(100 \%)$ & $0 / 2 / 0$ & $2(100 \%)$ & $0 / 2 / 0$ & $1(50 \%)$ \\
\hline 5 & Choi [12] & 2004 & 500 & $22(4.4 \%)$ & NA & $10 / 8 / 4$ & $2(9.1 \%)$ & $2 / 0 / 0$ & $4(18.2 \%)$ \\
\hline 6 & Tien [4] & 2005 & 402 & $10(2.5 \%)$ & $10(100 \%)$ & $3 / 7 / 0$ & $0(0 \%)$ & $0 / 0 / 0$ & $5(50 \%)$ \\
\hline 7 & Fujii [13] & 2007 & 351 & $8(2.3 \%)$ & $6(75 \%)$ & $6 / 2 / 0$ & $1(12.5 \%)$ & $1 / 0 / 0$ & $4(50 \%)$ \\
\hline 8 & Beyer [14] & 2009 & 87 & $9(10.3 \%)$ & $6(66.7 \%)$ & $8 / 1 / 0$ & $4(44.4 \%)$ & $4 / 0 / 0$ & $0(0 \%)$ \\
\hline 9 & Lee [15] & 2010 & 907 & $27(3 \%)$ & $12(44.4 \%)$ & $23 / 2 / 2$ & $4(14.8 \%)$ & $4 / 0 / 0$ & $6(22.2 \%)$ \\
\hline 10 & Feng [6] & 2014 & 840 & $54(6.4 \%)$ & $26(48.1 \%)$ & $13 / 8 / 33$ & $10(18.5 \%)$ & $3 / 4 / 4$ & $16(29.6 \%)$ \\
\hline 11 & Jilesen [16] & 2014 & 1,035 & 47 (4.5\%) & 19 (61.7) & $16 / 4 / 27$ & $0(0 \%)$ & $0 / 0 / 0$ & $6(12.8 \%)$ \\
\hline 12 & Huo [17] & 2015 & 357 & $21(5.9 \%)$ & $14(66.7 \%)$ & $18 / 3 / 0$ & $6(28.6 \%)$ & $5 / 0 / 1$ & $5(23.8 \%)$ \\
\hline & Total & & 5,659 & $246(4.3 \%)$ & $122(49.6 \%)^{c}$ & $113 / 63 / 71$ & $34(13.8 \%)$ & $22 / 8 / 5$ & $60(24.4 \%)$ \\
\hline
\end{tabular}

a Intervention included TAE and covered stent, another included angiography examination or gastrointestinal endoscopy or conservative treatment. b Intervention included TAE and covered stent, another included conservative or uncontrolled bleeding. ${ }^{\mathrm{c}}$ Except case No. 5. NA, not assessed. 